\title{
8 Appendices
}

\subsection{Appendix A - NYSSV Membership}

New York Society for the Suppression of Vice (NYSSV), Short biographies of some of the original founders.

Thatcher M. Adams Lived at 63 E. $79^{\text {th }}$ Street in New York after buying 123 acres of land from Emile Grigsby, mistress of Charles Yerkes, Chicago street car magnate.

Cornelius R. Agnew (1830-1875) Physician who was appointed the Surgeon General of New York in 1858. Founded the Brooklyn ear and eye hospital in 1868 and was elected President of the York Medical Society in 1872.

J.M. Cornell Along with J.B. Cornell, he owned a wrought and cast iron company that supplied materials for the Washington Monument.

William Earl Dodge, Jr. (1805-1883) Businessman and abolitionist. Builder of the Macon and Brunswick Railroad, after the Civil War. Influential in the post-war Native American reform movement.

Morris Ketcham Jessup (1830-1908) First President of the YMCA. Banker and philanthropist. One of the founders of Syrian Protestant College, later called the American University in Beirut. Organizer of the American Museum of Natural History. One of the original trustees of the Slater Fund, along with Rutherford B. Hayes and William E. Dodge.

Elbert B. Monroe Trustee of the Hampton Institute, a black, mulatto and Indian university founded after the Civil War in Hampton, Virginia. His wife was the niece of Frederick Marquant (1799-1882) a jeweler and merchant who retired at age 40 to devote his life to philanthropy.

John Pierpoint Morgan (1813-1890), Banker, who in the late 1800s founded the most powerful banking house in the world. The company, J.P. Morgan \& Co., financed the formation of the U.S. Steel Corporation and arranged the merger of Edison General Electric and Thomson-Houston Electric companies to form General Electric. The company also bought and reorganized 4 of the 5 major American railways between 1869 and $1899 .^{1318}$

\subsection{Appendix B - Indiana's Sterilization Statute}

Indiana's Sterilization Statute (Full Text)

Passed 1907

House Vote: $59-22$

Senate Vote: $28-16$

1318 Ibid. 
Table 8.1: CMHVS members and number of committee appointments

\begin{tabular}{|c|c|c|c|c|c|c|c|c|c|c|}
\hline $\begin{array}{l}\text { CMHVS Members and Number of } \\
\text { Committee Appointments }\end{array}$ & $\frac{\frac{\delta}{\sigma 0}}{\stackrel{0}{\pi}}$ & $\begin{array}{l}\stackrel{\hat{D}}{x} \\
\text { âd }\end{array}$ & 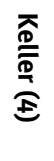 & $\begin{array}{l}\frac{0}{\frac{0}{7}} \\
\text { D্ } \\
\text { ज্ }\end{array}$ & $\begin{array}{l}\overbrace{0}^{0} \\
\stackrel{0}{0} \\
\text { ज్ }\end{array}$ & 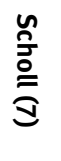 & $\begin{array}{l}\frac{n}{3} \\
\frac{1}{0} \\
\stackrel{0}{0} \\
\text { ज़ }\end{array}$ & $\begin{array}{l}\text { S } \\
\frac{N}{2} \\
\text { E }\end{array}$ & 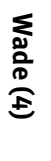 & 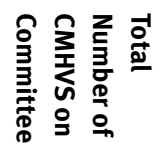 \\
\hline Affairs of Reformatory & & & & & & $\mathrm{x}$ & & & & 1 \\
\hline Affairs of State Prison & & $\mathrm{x}$ & & & & & & & & 1 \\
\hline Banks & & $x$ & & & & & & & & 1 \\
\hline $\begin{array}{l}\text { Benevolent and Scientific } \\
\text { Institutions }\end{array}$ & & & & $\mathrm{x}$ & $\mathrm{x}$ & & & & & 2 \\
\hline Building Loan & & $\mathrm{x}$ & & & & $\mathrm{x}$ & & & & 2 \\
\hline Education & & & & & $\mathrm{x}$ & & $x$ & & & 2 \\
\hline Engrossed Bills & & & & & & & & $\mathrm{x}$ & & 1 \\
\hline Federal Relations & & & & & & & $\mathrm{x}$ & & & 1 \\
\hline Fees and Salaries & & & & & & $\mathrm{x}$ & & & & 1 \\
\hline Legislative Apportionment & $x$ & & & & & & & & & 1 \\
\hline Manufacture and Commerce & & & & & & & $x$ & & & 1 \\
\hline Mileage and Account & & & & $\mathrm{x}$ & & & & & & 1 \\
\hline Public Libraries & & & & & & & & & $\mathrm{x}$ & 1 \\
\hline Reformatory Institutions & & & & & & & & & $\mathrm{x}$ & 1 \\
\hline Rights and Privileges & & & $x$ & $\mathrm{x}$ & & & & $\mathrm{x}$ & & 3 \\
\hline Rivers and Waters & & & & & $x$ & & & & & 1 \\
\hline Roads & & & & & & & & $\mathrm{x}$ & & 1 \\
\hline Phraseology of Bills & & & & & & & $x$ & & & 1 \\
\hline Printing & & & & $x$ & & & & & & 1 \\
\hline Sinking Fund & & $\mathrm{x}$ & & & & & & & $x$ & 2 \\
\hline Soldiers Monuments & & & & & & $\mathrm{x}$ & & & & 1 \\
\hline State Library & & & & & & $\mathrm{x}$ & & & & 1 \\
\hline $\begin{array}{l}\text { State Medicine, Health and Vital } \\
\text { Statistics }\end{array}$ & $x$ & $x$ & $x$ & $x$ & $x$ & $\mathrm{x}$ & $\mathrm{x}$ & $x$ & $x$ & 9 \\
\hline Statistics and Immigration & & $x$ & $x$ & & & & & & & 2 \\
\hline Telegraph and Telephone & & & & & & $\mathrm{x}$ & & & & 1 \\
\hline Trusts and Funds & & & & & $\mathrm{x}$ & & & & & 1 \\
\hline Ways and Means & & & $\mathrm{x}$ & & & & & & & 1 \\
\hline
\end{tabular}


AN ACT to prevent the procreation of confirmed criminals, idiots, imbeciles and rapists: Providing that superintendents or boards of managers of institutions where such persons are confined shall have the authority and are empowered to appoint a committee of experts. Consisting of two physicians, to examine into the mental condition of such inmates. WHEREAS, heredity plays a most important part in the transmission of crime, idiocy, and imbecility:

THEREFORE, BE IT ENACTED BY THE GENERAL ASSEMBLY OF THE STATE OF INDIANA, that on and after the passage of this act it shall be compulsory for each and every institution in the state, entrusted with the care of confirmed criminals, idiots, rapists and imbeciles. To appoint skilled surgeons of recognized ability, whose duty it shall be, in conjunction with the chief physician and board of experts and the board of managers. If in the judgment of this committee of experts procreation is inadvisable, and there is no probability of improvement of the mental and physical condition of the inmate, it shall be lawful for the surgeons to perform such operation for the prevention of procreation as shall be decided safest and most effective. But this operation shall not be performed except in cases that have been pronounced unimproveable. Provided that in no case the consultation fee be more than three dollars to each expert, to be paid out of the funds appropriated for the maintenance of such institution. ${ }^{1319}$

\subsection{Appendix C - Composition of CHMVS and Committee Appointments}

\section{Committees, 1907 Indiana General Assembly}

Committee on Health, Medicine and Vital Statistics (CHMVS), as reported in Indianapolis News, 14 January 1907, p. 3.

\section{CHMVS: Porter, Coble, Cox, Keller, Read, Scholl, Simison, Vizard, Wade}

Chairman: Dr. A.W. Porter (R), Martin and Orange Counties. Member of 5 committees, Chair of CHMVS.

Members:

- Rep. Coble (D) of Dubois and Pike Counties, resided in Stendal. Member of 3 committees.

- Senator Lincoln A. Cox ${ }^{\star}$, (), Marion County: on 6 committees.

- $\quad \operatorname{Keller}(\mathrm{R})$ of Marion County: Member of 4 committees.

- Dr. Horace D. or G. Read, (R), Tipton and Hamilton Counties: Member of 5 committees.

- Rep. Dr. Scholl (R), Carroll, Howard and Miami Counties: Member of 6 committees.

1319 Document URL: http://www.kobescent.com/eugenics/statute.html, accessed May 1, 2014. 
- $\quad$ Rep. Dr. J. Frank Simison (R), Montgomery and Tippecanoe Counties: Member of 4 committees.

- Dr. John Wellington Vizard (D), Adams County, Pleasant Mills: Member of 4 committees.

- Frank J. Wade (D), Posey County: Member of 3 committees

* There were two legislators named Cox, and one was Lincoln A Cox on the CHMVS.

\section{Other Doctors in the Legislature:}

In the Senate:

- Dr. Richard R. McCain of Kentland, Chair of Senate Committee

- Dr. O.M. Keyes of Dana

- Dr. Charles R. Lane of Ft. Wayne

- Dr. McDowell of Sullivan and Knox Counties

\subsection{Appendix D - Composition of the 1934-1936 Norwegian Storting by Party Affiliation, Region and Occupation}

Composition of 150-Member 1934-1936 Norwegian Storting by Party (Source: http://www.norgeslexi.com/politikk/storting/representatnt/34-36.html last accessed 9 December 2007)

\section{Party Affiliation}

\section{Labour Party (Arbeiderparti) - 68}

T. Haaverstad - Aust-Agder, A. Udland - Vest-Agder, O.J. Olsen - Vest-Agder and Rogaland, I.J.S. Førre - Vest-Agder and Rogaland, K.M. Nordanger - Akershus, H. Halvorsen - Akershus, B. Korslund - Akershus, Fru Helga A.A. Ramstad Akershus, J. Samuelsen - Bergen, G.O.O. Bakke - Bergen, C. Hornsrud - Buskerud, N.A. Steen - Buskerud, H.J. Jensen - Buskerud, A.R. Moss - Buskerud, A. Nygaard Buskerud, K.H. Berg - Finnmark, A.K. Mikkola - Finnmark, O.V. Nilssen - Hedmark, O. Sæter - Hedmark, K.T. Sjøli - Hedmark, P.E. Vorum - Hedmark, K. Fonstad Hedmark, C.F. Monsen - Hedmark and Oppland, N. Ødegaard - Hedmark and Oppland, K.O. Bergsvik - Hordaland, G.B. Forstøm - Hordaland, O.B. Oksvk - Møre and Romsdal, A.L. Alvestad - Møre and Romsdal, J.U. Olsen - Møre and Romsdal, A.J.H.H. Moan - Nordland, C.L. Enge - Nordland, C.E.C. Bonnevie - Nordland, J.O. Steffensen - Nordland, J.A. Andrå - Nordland, Troms and Finnmark, J.B. Olsen Nordland, Troms and Finnmark, J. Bøe - Oppland, L.M. Moen - Oppland, M. Smedby Oppland, A.M. Madsen - Oslo, M. Nilssen - Oslo, O.J. Johensen - Oslo, Fru Helga A. Karlsen - Oslo, I.K. Hognestad - Rogaland, A.M.A. Lothe - Sogn and Fjordane, O.M.K. Stennes - Telemark, O.A. Versto - Telemark, O.T. Vegheim - Telemark, O. Solberg - Telenmark and Aust-Agder, A. Nilssen - Telenmark and Aust-Agder, 
M.N. Foshaug - Troms, W.A. Ingebrigtsen - Troms, A.J. Johansen - Troms, A.J. Moen Nord-Trøndelag, J. Wiik - Nord-Trøndelag, J. Nygaardsvold - Sør-Trøndelag, S.K.E. Skarholt - Sør-Trøndelag, M.A. Salbubæk - Sør-Trøndelag, S.K.E. Støstad Sør and Nord-Trøndelag, I. Aarseth - Sør and Nord-Trøndelag, J. Mathassien - Vestfold, A.M. Jenssen - Vestfold, K.A. Christiansen - Vestfold, J.O. Bergersen - Østfold, P.O. Thorvik - Østfold, A.T. Svendsen - Østfold, J.E. Pettersen - Østfold and Akershus, J.L. Johannesen - Østfold and Akershus, A. Akre - Østfold and Akershus.

\section{The Liberal Party (Venstre) - 25}

C. Stray - Aust-Agder, G.J. Eiesland - Vest-Agder, B. Olsen-Hagen - Vest-Agder and Rogaland, L.K.N. Rygh - Vest-Agder and Rogaland, R.E. Peersen - Vest-Agder and Rogaland, J.L. Mowinckel - Bergen, O.M. Mjelde - Hordland, O.J. Myklebust - Hordaland, M.A.A. Kårbø - Hordaland, O.R.K. Flem - Møre and Romsdal, J.M.J. Strand Møre and Romsdal, P. Ø Syltebø - Møre and Romsdal, R. Anderssen-Ryst - Møre and Romsdal, J.J. Caroliussen - Nordland, J.I. de Kobro - Nordland, Troms and Finnmark, K.K. Kleppe - Rogaland, K. Edland - Rogaland, J.M.A. Lothe - Sogn and Fjordane, H.K. Seip - Sogn and Fjordane, N. Valen -Telemark, A. Alexander - Telenmark and Aust-Agder, A.K.H. Jakobsen - Troms, H.M. Five - Noard-Trøndelag, S.O. Leinum Sør-Trøndelag, N.M. Tvedten - Vestfold.

\section{Conservative Party (Høyre) - 30}

J.M. Ørbeæk - Aust-Agder, B.A.B. Skeibrok - Vest-Agder, S. Nielsen - Vest-Agder and Rogaland, K. Jacobsen - Vest-Agder and Rogaland, O.L. Bæroe - Akershus, H. Gram Akershus, T.B. Mowinckel - Bergen, J.R. Aas - Buskerud, S.A. Svensen - Buskerud, C.R. Olsen - Finnmark, J.A. Svendsen - Hedmark and Oppland, I.J. Bleiklie - Hordaland, E.H.P. P. Præsteng - Nordland, O. Fjalstad - Nordland, Troms and Finnmark, C.J. Hambro - Oslo, E. Getz - Oslo, A.H.E. Nordlie - Oslo, T. Vinje - Rogaland, S.C. Brinch - Telenmark and Aust-Agder, E.A. Johansen - Telenmark and Aust-Agder, M.S.P. Laberg - Troms, J.O.O. Asmundvaag - Sør-Trøndelag, I. Lykke - Sør and NordTrøndelag, Frk. Signe Swennsson - Sør and Nord-Trøndelag, N.J. Shjerven - Vestfold, S.F. Brunn - Vestfold, T. Sverdrup -Vestfold, H.J. Sollie - Vestfold, I. Undrum Østfold, H.S. Bakke - Østfold and Akershus.

\section{The Farmers' Party (Bondepartiet) - 23}

N. Nerstan - Aust-Agder, G.E. Moseid - Vest-Agder, J. Sundby - Akershus, K.H. Tandberg - Buskerud, O. Øst-Deglum - Hedmark, L.O. Aukrust - Hedmark, J.N. Vik Hordaland, R.O. Langeland - Møre and Romsdal, M. Trædal - Møre and Romsdal, L.S. Rommundstad - Møre and Romsdal, N.K.N. Mjaavatn - Nordland, H.N. Hanssen Nordland, K. Ørud - Oppland, E. Bjørnson - Oppland, N.M. Kverneland - Rogaland, G.A. Hegernes - Sogn and Fjordane, P.T. Hovland - Sogn and Fjordane, J.F. Hundseid - Telemark, I.L. Kirkeby-Garstad - Nord-Trøndelag, E. Müller - Nord-Trøndelag, 
M.H. Handberg - Sør-Trøndelag, A. Maastad - Østfold, B. Braadland - Østfold and Akershus.

Society Party (Samfundsparti) - 1 B.D. Brochmann - Bergen

Kr and F - 1 N. Larvik - Hordaland

R and F - 1 A. Mjøen - Oppland

F and F - 1 R.R. Ræder - Sør and Nord-Trøndelag

\section{Occupations}

Arbeidsformann (Work Foreman) - 1

Assistant - 1

Bakermester (Master Baker) - 1

Bankdirektør and gårdbruker (Bank Director and Farmer) - 1

Banksjef (Bank Manager) - 1

Bibelskolebestyrer and gårdbruker (Bible School Prinicipal and Farmer) - 1

Bokhandler (Bookshop) - 1

Bryggearabeider (Construction Worker) - 1

Direktør and ingenør (Director and Engineer) - 1

Direktør and major (Director and Major) - 1

Fabrikkarbeider (Manufacturing Worker) - 3

Fisker (Fisherman) - 3

Fisker and småbruker (Fisherman and Small Farmer) - 1

Fiskeriinspektør (Fishery Inspector) - 1

Fullmektig (Law Clerk) - 1

Fylkeskasserer (District Treasurer) - 1

Fylkesmann (Chief Administrative Officer of a District) - 1

Gårdbruker (Farmer) - 29

Gårdbruker and bankasserer (Farmer and Bank Cashier) - 1

Gårdbruker and fanejunker (Farmer and Highest Non-Commissoned Officer) - 1

Gårdbruker and fisker (Farmer and Fisherman) - 2

Gårdbruker and landbrukslærer (Farmer and Agriculture Teacher) - 1

Gårdbruker and poståpner (Farmer and Post Opener) - 1

Gårdbruker and statsrevisor (Farmer and State's Accountant) - 1

Generalsekretære (General Secretary) - 1 Gullsmed (Jeweler)- 1

Havne- og transportarbeder (Ocean and Transportation Worker) - 1

Herredskasserer (Township Treasurer) - 1 Hovedkasserer (Head Cashier) - 1

Høyesterettsadvokat (Attorney entitled to practice before the Supreme Court) - 2 
Jordbrukkonsulent (Agricultural Consultant) - 1

Kaiarbeider (Wharf Worker) - 1

Kontorsjef (Office Manager) - 2

Kjøpmann (Merchant) - 4

Kommunearbeider (Municipal Worker) - 1

Kommunerevisør (Municipal Accountant) - 1

Konsul (Consul) - 1

Kontrollør (Inspector) - 1

Lagerarbeider (Warehouse Worker) - 1

Landsbrukssekretær (Agriculturer Secretary) - 1

Landbrukslærer (Agricultural Teacher) - 1

Landbruksskolebestyrer (Agricultural School Principal) - 3

Lektor (Secondary School or University Teacher)- 1

Lege (Doctor) -1

Lensmann (Administrative Official) - 3

Lærer and Gårdbruker (Teacher and Farmer) - 1

Lærer (Teacher) - 7

Major and Skogeier (Major and Forest Owner) - 1

Marinekaptein (Sea Captain) - 1

Maskinist (Machinist) - 1

Murmester (Masonry Master) - 1

Oberstløytnant and gårdbruker (Lieutenent General and Farmer) - 1

Overingeniør (Head Engineer) - 1

Papirarbeider (Paper Worker) - 1

Prost (Cathedral Dean) - 1

Redaktør (Editor) - 8

Rektor (President of University/Principal of Secondary School) - 1

Sagarbeider (Sawmill Worker) - 1

Skipsreder (Ship Owner) - 1

Skolebestyrer (School Princpal) - 3

Skoleinspektør (School Inspector) - 3

Skreddermester (Master Tailor) - 1

Småbruker (Small Farmer) - 8

Småbruker and fisker (Small Farmer and Fisherman) - 2

Snekker (Cabinet Maker) - 1 
Sorenskriver (Chief Judge of a Rural District) - 2

Sosiologisk Forfatter (Sociology Author)- 1

Statsråd (Cabinet Minister) - 3

Statsadvokat (Prosecuting Attorney) - 1

Statsminister (Prime Minister) - 1

Statsrevisor (State Accountant/Treasurer) - 1

Steinarbeder (Stone Worker) - 1

Telekontrollør (Telegraph Inspector) - 1

Telegrafissst (Telegrapher) -1

Underfoged (Assistant Tax Collector) - 1

Vaktmester (Caretaker) - 2 Verkmester (Plant/Mill Manager) - 2

\section{Party Distribution in 150-Member Storting}

Labour Party (Arbeiderparti) - 68 Members (45.3\%)

Conservative Party (Høyre) - 30 Members (20\%)

Venstre - 25 Members (16.6\%)

B Party - 23 Members (15.3\%)

Society Party (Samfundsparti) - 1 Member (0.6\%)

$\mathrm{Kr}$ and F Party - 1 Member (0.6\%)

$\mathrm{R}$ and $\mathrm{F}$ Party -1 Member (0.6\%)

$\mathrm{F}$ and $\mathrm{F}$ Party -1 Member $(0.6 \%)$

\section{Approximate Occupation Percentages of 150-member Storting}

Bank/Merchant/Manager - 16 (10.6\%)

Blue collar - 18 (12\%)

Farming - $46(30.6 \%)$

Fishing - $4(2.6 \%)$

Professional (Attorney/Doctor/Engineer/Lector/Rector) - 6 (4\%)

State Administrative/Professional - 20 (13.3\%)

Teacher - $10(6.6 \%)$

White Collar - $30(20 \%)$ 


\subsection{Appendix E - Translation of Storting Debate, $1934^{1320}$}

Translation of the transcript from the 9 May 1934 Storing Committee meeting, called to order at 12:15 P.M. The President was Eiesland. The meeting lasted 2 hours and 10 minutes and handled 8 items. The seventh item was the "Instilling fra justiskomiteen til lov om adgang til sterilisering m. v. (Innst. O. nr. 46). The debate was taken from Volume 8 of the 1934 multi-volume Stortingsforhandling, published by the Centraltrykkeviet in Oslo, 1934. The debate began on page 157 of Volume 8 and ended on page 161 , followed by a copy of the law.

\section{Committee Members}

- Storting Representative E. Bjørson (Bonde Party) from Oppland District

- Storting Representative Bonde (Alternate for B.D. Brochmann) (Samfundsparti) from Bergen District

- $\quad$ Storting Representative C.E.C. Bonnevie (Labour Party) from Nordland District

- Storting Representative O. Fjalstad (Conservative Party) from Nordland, Troms and Finnmark District

- Cabinet Minister Sunde

\section{Sak Nr. 7}

Item Number 7

Instilling fra justiskomiteen til lov om adgang til sterilisering m.v. (Innst. 0. nr. 46)

The Report from the Justice Committee regarding the Law on Access to Sterilization submitted as Odelstinget Proposition Number 46.

Saka i det heile vart sett under debatt. The entire Report was open for debate.

Bjørnson (Komiteens ordfører): Det er naturlig at Bjørnson (The Chair of the Committee): It is valget til å fremlegge denne proposisjon er falt natural that the choice of someone to talk about på en bonde. For der er ingen som gård brukerne der daglig kan iaktta den uhyre fordel som en this bill has fallen to a farmer. For there is no one like a farmer who can, on a daily basis, observe gjennomført rasehygiene har for gårdsdriften og dermed for det hele land Dette gjelder ikke bare buskapen, men også alle nyttevekster som landbruket er avhengig av. På den ene side går våre bestrebelser ut på å sikre en kraftig, avlsdyktig og ydende stamme, på den annen side å befri the enormous advantage that comes from race hygiene in the management of the farm and therefore for the entire country. This concerns not only animal husbandry but also all the new crops that farming is dependent upon. On the one hand are our efforts to produce powerful, genetically sound den for snyltedyr og ukrutt. Bare ugresset koster and productive stock and, on the other hand, is landet mange millioner kroner om året. our ability to free this stock from the parasites and weeds cost the country millions of kroner annually.

1320 My sincere thanks to Professor Sissel Jensen Nefzaou and to Professor Sætnan for their assistance in this translation; all mistakes in translation or meaning are ultimately mine. 
Stortinget har ved lovkraft og bevilgninger i mange år støttet arbeidet for å fremme folkehelsen og deler med videnskapen æren for at folkets gjennomsnittsalder $\mathrm{i}$ betydelig grad er gått frem. Mens den for vel 50-år siden lå under folkets kraftigste alder, ligger den nu adskillig år over. Som et samlet folk er vi idag nesten tyve år eldre enn den generasjon var som våre forfedre tilhørte. Man kan si at der aldri før har levd i Norge en så gammel folkegenerasjon. Det bør man merke sig, og det ser ut som grensen ennu ikke er nådd, for så virksomt arbeider videnskap og folkeviljen hånd $\mathrm{i}$ hånd om å trygge de enkeltes liv. En naturlig utvikling av de forandrede forhold har vært at det arbeidsdyktige samfund er blitt belastet med økede utgifter til alderstrygd og sykebehandling samt andre byrder i forbindelse hermed. Mens det for 40 à 50 år siden var en skam å komme på forsorgen er det $\mathrm{i}$ de nye tiders forholds medfør blitt en selvfølgelighet at samfundet trygger en sorgfri alderdom og hjelper de ikke arbeidsdyktige til utkomme. Skattene og avgiftene stiger og umiliggjør selv for den flinkeste og sparsomste å legge såpass til side at han kan sørge for sig og sine. Det er ikke tvil om at det moderne samfund allerede i så henseende viser tegn på at det er overbelastet. Det gjelder derfor mer enn nogen sinne at den arbeidsdyktige stamme ved rasehygiene blir så kraftig som mulig, så den kan overkomme kravene uten å miste sitt livsmot.

Over many years the Storting, through its laws and appropriations, has supported the work to advance the health of citizens and shares with science the honor to have increased the average age of our citizens to a meaningful degree. Fifty years ago the average age was less than the age when people are at their strongest but now this age has been increased by several years. As a nation, we are today nearly 20 years older than the generation to which our parents belonged. One can say that there has never before lived in Norway a generation that has lived to such an advanced age. One should pay attention to this and it looks like the limit hasn't been reached yet because science and the will of the people, working hand in hand, works in such an effective way to secure the life of the individual. A natural development from the changed situation, has been that the those who are the able-bodied workers* of society have become saddled with rising taxes for the old age pensions and hospital care together with other burdens in connection with this. While, forty or fifty years ago, it was a disgrace to receive welfare, we now have a new situation in which it is obviously a matter of common knowledge that society secures a worryfree old age and helps those who are not ablebodied workers to have enough at their disposal. Taxes and fees are rising making it impossible for even the most capable and parsimonious to put something aside so that he can provide for himself and his own family. There is no doubt that modern society, in this respect, already shows signs that it is overburdened. It is important therefore, more than ever, that the able-bodied working stock of people, through race hygiene, become as powerful as possible, so that they can overcome all these demands without losing their own will to live.

Det er med dette syn på fremtiden at Tyskland er gått til tvangssterilisering for å befri de kommende generasjoner for å trekkes med an overbelastning av degenererte mennesker. Det skjer således til fordel for dem som har gjort sin plikt like overfor samfundet og nu som gamle kun kan følge begivenhetene, så vel som til fordel for den yngre generasjons sundhet og utdannelse. Av frykt for at der ikke skal bli nok unge krefter
It is with this view of the future that Germany has enacted forced sterilization in order to free the coming generations from being burdened with degenerate humans. This benefits those who have done their duty to society and now as aged can only watch and follow whatever happens. There will also be an advantage for the health and education of the younger generation. Out of fear that there will not be enough young people to bear the 
til å bære byrdene, utbetales der nu i Tyskland flere hundre millioner kroner til fremme av nye ekteskaper. Så alvorlig tar de saken der. burdens, there is now in Germany the disbursement of many hundred millions of kroner to help new marriages. So seriously do the Germans take these matters.

It is already clear to anyone who is trying to understand these questions and who is willing to see that conditions are developing in such a direction that will make it imperative to breed people and one now breeds animals if one will be able to secure for the population a happy and secure future. With this type of force of necessity as background before us, this bill is a mild attempt. Our descendants will perhaps criticize us that we did not immediately take more drastic measures when the necessity for them was assurg edly in place, and the law of genetics demand that we deal with this quickly and thoroughly. This bill allerede nu å gå et skritt videre, og åpne adgang further and open access to forced sterilization. til tvungen seksualinngrep, og blir der optatt forslag herom, akter iallfall, jeg å stemme for dette. Når vi i komiteen ikke har fremsatt forslag herom, var det av frykt for at det da kunne gå med denne lov som med den jeg sist forsvarte har i Odelstinget, som vi desverre ikke fikk det And, should this proposal come about I, for one, intend to vote for it. When we here in the committee have not advanced the bill to that point, it was out of fear that the result would be the same with this law as happened to the last bill I defended here in the Odelsting, which we unfortunately mer konservative, og kanskje mer bigotte Lagting couldn't make the more conservative and perhaps til å gå med på. Jeg mener loven om å gi kvinnene more biased Lagting to go along with. I refer to samme rett til å bli prester som menn. Dertil the law that would have given women the same right as men to become priests. In addition, this kommer at selve loven som vi foreslår den, er i og for sig en utmerket lov, som med et slag setter law itself, in the way we propose it, is a remarkvårt land in rang med de mest fremskredne land på dette område.

able law which, with one sudden blow, sets our country in the same position as the most progressive countries in this area.

Jeg synes ikke jeg kan avslutte dette mitt innlegg uten å få takke statråd Sunde for at han har tatt denne sake op og fremlagt det utmerkede lovforslag, som vi nesten uten endring har fulgt. Men jeg vil også fra denne plass få sende vår anerkjennende takk til de menn og kvinner som har modnet denne sak i vårt folk, så den nu idag vil gå sin sikre vandring til lov. Særlig vil jeg nevne Den norske rådgivende komité for rasehygiene med dens utrettelige leder dr. Alfred Mjøen, som ved denne loves vedtagelse vil få den anerkjennelse også i vårt land, som han for lengst har erhvervet ute i verden.
I don't feel that I can close my introductory remarks without thanking minister Sunde since he has picked up this cause and proposed this splendid bill, which we have followed almost with any change. But, at this time, I also want toextend dan appreciative thanks to those men and women who have matured this cause with our citizens, so that now, today, it will certainly follow its certain path into law. I want especially to thank The Norwegian Advisory Committee for Race-Hygiene and its indefatigable leader Dr. A. Mjøen, who, with this law's passage, will also get the recognition in our country which he has had for such along time out in the world. 
Til slutt må jeg gjøre opmerksom på at annen linje i §7 skal det stå « befatning med steriliseringssaker 》 istedenfor ordene 《< behandling med steriliseringssaker $\gg$.

Bonde: Jeg har ikke det samme syn på det lovforslag som her er fremlagt, som komiteens ordfører nettop gav uttrykk for. Jeg finner at dette lovforslag, som idag er lagt frem for Odelstinget er et av de farligste lovforslag som overhode har sett dagens lys i landet.

Det er jo klart det må være et visst forhold mellom samfund og individ, men der er i dette tilfelle rettet et angrep på individet, hvorved man i høi grad retter baker for smed. Vi må jo husker på at forbryderne blir ikke forbrytere i kraft av sig selv, men de blir forbrytere ikke minst i kraft av det miljø, de omgivelser de lever i. Det er de samfundsforhold vi lever under som skaper forbryterne, - de forbryter vi har det er prisen vi må betale for de dårlige samfundsforhold. Når vi legger sedelighetsforbryteren hans forbrytelse til last og dømmer ham, så er vi på feil vei. Det er underlig at vi i et land, hvor vi snakker om 900 års kristendom, fullstendig har glemt vår barnelærdom. Det var en mann for 1900 år siden som sa i en lignende situasjon: Den som er uten skyld, han kaste den først sten. Men vi i Norges Stortinget, anno 1934, vi kaster sten alle sammen. Vi innbys her i Odelstinget til å dømme individet for det som vi selv gjennom vår samfundsorden har ansvaret for. Løsningen av dette spørsmål er ikke den at vi skal gå til voldelige inngrep på individet, men løsningen, den eneste varige løsning - og også den eneste mulige rasehygiene i lengden - er den ting at vi får endret på de samfundsforhold vi lever under og dermed redusert forbrytelsenes antall. Jeg mener der er barbarisk og middelaldersk å la individet lide for det som samfundet har skylden for.
In closing, I want to point out that the second line in $§ 7$ should read "connection with sterilization cases" instead of the words "treatment of sterilization cases."

Bonde: I do not feel the same about this bill, which has been proposed by the committee Chairman who just spoke for it. I find that this proposal that is placed before the Odelsting today is one of the most dangerous proposals ever to see the light of day in this country.

It is clear that there has to be a certain relationship between society and the individual, but, in this case, the law directs an attack on the individual, which, to large degree, makes the innocent suffer for the guilty. We have to remember that criminals do not become criminals by virtue of themselves but they become criminals, not the least through the environment and the surroundings in which they live. It is these societal influences that we live in that create the criminals, these criminals that we have, that's the price we must pay for the bad social conditions. When we accuse and convict the sexual criminal for his crime, we are on a mistaken course. It is strange that in a country, where we talk about 900 years of Christianity, that we have completely forgotten our catechism lessons. There was one man 1900 years ago who, placed in a similar situation who said, "Let he who are without guilt caste the first stone." But we here in the Norwegian Parliament, in the year 1934, we are all casting stones. We are invited here in the Odelsting to judge the individual that we, through our own social order, have responsibility for. The solution to this question, to this violent attack on the individual, theonly lasting solution - and also the only possible race hygiene in the long run - is that we must change societal conditions under which we live and through this secure a reduction in the number of criminals. I believe that it is barbaric and medieval to let the individual suffer for something that society has the blame for.

Min oppfatning er at det er en slett forberedelse det fremlagte lovforslag har vært gjenstand for. Det er jo klart at den nye videnskap som går sin seiersgang over hele verden, den nye psykologi og psykoanalyse har et helt annet syn på
My opinion is that the proposed law that is before us has been badly prepared. It is clear that the new science which goes in a triumphant procession around the entire world, the new psychology and psychoanalysis has a totally different attitude 
forbryterer og forbrytelser enn den gamle hedensk-romerske opfatning som ligger til grunn for vårt juridiske system. Det er jo på det rene at en sedelighetsforbryter utfører sin forbrytelse i en sjelelig $n ø d$, det er de sjelelige forhold ved individet som skaper forbryteren og man forbedrer ikke en forbryter ved å sperre ham inne i et fengsel. Vil man være sikker på at man ikke skal få uskadeliggjort en sedelighetsforbryter så skal man sette ham i et fengsel en 2-3 år og så slippe ham ut igjen, for da er det noget som er helt klart at han er ti ganger verre enn da han blev satt inn. Men den nye videnskap er fullt klar over at en sedelighets (page 159) forbryter kan sjelelig helbredes gjennom psykologisk påvirkning. Psychoanalysen har nettop som opgave å gjøre også forbrytere til nyttige samfundsmennesker igjen. Det er en utredning av de forhold, vi savner i forberedelsen til denne lov.

Jeg vil på det bestemteste advare mot at man treffer nogen beslutning om dette lovforslag idag. Jeg vil foreslå at saken utsettes, inntil den også er utredet på det område den nye videnskap her er kommet til, og som hele verden over nu vekker den største opmerksomhet.

Bonnevie: Jeg tror at denne sak har fått en meget omhyggelig forberedelse. Det som kunde sies å mangle i lovens forberedelse og forarbeid er vel dette ene at de synsmåter som samfundspartiet representerer, ikke har fått gjøre sig gjeldende, men ellers mener jeg at den i alle deler er vel forberedt. Jeg mener også at de uttalelser representanten Bonde kom med i virkeligheten helt skyter over mål. Så lenge lovforslaget ikke har møtt motsigelse fra noget annet hold enn samfundspartiet, og da vi her står foran en enstemmig instilling, akter jeg ikke å komme nærmere inn på denne lov og det alvorlige materiale den gjelder. Jeg vil bare som sagt presiser at hr. Bonde skyte over mål.

Dette lovarbeid gjelder jo dels sterilisering og lignende forholdsregler overfor dem som frivillig samtykker i det; dernest gjelder det seksualinngrep overfor sinnssvake og åndssvake personer, nærmere angitt i loven. Dette siste inngrep er i realiteten et slags tvunget inngrep fordi disse sinnssvake eller åndelig mindre towards criminals and crimes than does the old pagan-roman experience that lies at the foundation of out legal system. It is clear that a sexual criminal commits his crime in a state of mental despair and it is this mental state that creates the crime and one cannot cure the criminal by locking him up in a prison. If one intends not to cure the criminal, then one should put the sexual criminal in jail for 2-3 years and let him out again because there is nothing clearer than that he is ten times worse than when he was put in prison. But the new science is clear on that point that a sexual criminal can be mentally cured through the influence of psychology. Psychoanalysis has as its goal to remake criminals into useful social persons again. It is an account of these conditions that we miss in the preparation of this law.

I would warn very strongly against a decision on this bill today. I would suggest that the issue be set aside, until looked at in light of the new science that is receiving great attention now

throught the world.

Bonnevie: I believe that this issue has been given a great deal of painstaking preparation. The one thing one could say is missing in this preparation of the law and prepatory work of the law is the view represented by the Samfundsparti, which has not been considered, but otherwise I think that in all respects the bill is adequately prepared. I also think that the comments by Representative Bonde have actually missed the mark. As long as the bill has not encountered discrepancies other than those held by the Samfundsparti and as we have before us a unanimous proposal, I do not intend to pay any closer attention to this law and the serious content it contains. I only want, as I have said, to point out that Mr. Bonde has overshot his mark.

This prepatory law work concerns partly sterilization and similar measures concerning those who voluntarily partake in it; thereafter, it concerns the sterilization** of the mentally ill and the mentally weak $^{\star \star \star}$, more thoroughly explained in the law itself. This last intervention is in reality a type of forced intervention because these mentally ill 
utrustede, de samtykker ikke selv - det er ikke nødvendig, det er en verge eller kurator som samtykker. Men det som hr. Bonde nevnte og kom inn på, er den tredje gruppe. Det er tvangsinngrep overfor sedelighetsforbrytere, som altså hverken har gitt samtykke og som heller ikke er sinnssvake eller åndelig mindre utrustet. $0 \mathrm{~g}$ hvad denne tredje gruppe, altså disse sedelighetsforbrytere, angår så har ikke proposisjonen noget forslag, og den enstemmige komitéinnstilling har heller ikke på dette tidspunkt kommet med noget forslag. Det er bare slik at flere av komiteens medlemmer, som hr. Bjørnson sa, har forbeholdt sig der å stå fritt, og det kan man vel komme tilbake til ved behandlingen av den spesielle paragraph. Jeg skal bare på dette tidspunkt få tilføie at efter min opfatning må selvsagt individets rett veies overfor samfundets rett. Men det som har bidratt til at dette lovforslag som dette kommer frem, er naturligvis et dypere syn både på samfundets interesser og en dypere følelse av ansvar overfor efterslekten og de resultater i det hele tatt som arvelighetsforskningen har medført. Jeg vil sluttelig bare si at lovforslaget som det er tilblitt hos oss, er ikke et resultat bare eller fortrinvis av hvad man i Tyskland under Hitler har foreslått. Leser man proposisjonen eller leser man straffelovkomisjonens instilling eller andre forarbeider, ser man jo at det er arbeidet med denne sak også i andre land in Norden som utenfor Norden. Og en enkelt mann bør vel nevnes her, det er overlæge Johann Scharffenberg, som i høi grad med sine bidrag i pressen og for øvrig har bidratt til å reise denne sak. or mentally less endowed, they cannot consent on their own behalf - it is not necessary - there is a guardian or a social worker who consents. But that which Mr. Bonde has mentioned and brought forward is this third group. It is the forced sterilization of the sexual criminals that have neither given consent nor are mentally ill or mentally less endowed. And what concerns this third group, these sexual criminals, has not been referred to in the proposal nor has the unanimous committee report come up with a proposal at this time. It is only so that many of the members of the committee, which Mr. Bjørnson has said, have not taken a decision on it and it may be that one can come back to it by treatment in another special paragraph. At this point in time I shall only add that, in my opinion, the right of the individual must obviously be weighed against the right of society. But what has contributed to the fact that this bill has been advanced is naturally "a deeper view" of both society's interest and a deeper feeling of responsibility to our descendents and to the results that genetic research has brought forth. Finally, I want only to say that the bill, which has come before us here, is not the result only or primarily a result of what has been proposed in Germany under Hitler. If one reads the bill or if one reads the criminal commission's report or other prepatory work, one would see that there is work of this type in other countries both inside Scandinavia and outside it. And one individual man should clearly be mentioned here, and that is Medical Director Johan Scharffenberg, who has to a great extent contributed in the press and in other fields in bringing this bill to this point.

(The proposal is physically taken to the President's table and put on it.)

Presidenten: Representanten Bonde har teke op dette framlegget: « Ot. prp. 17 for 1934 tas ikke under behandling av inneværende års Odelsting. $\gg$

President: Representative Bonde has brought up this proposal: « Ot. prp. nr. 17 for 1934 should not be taken into consideration during the present year by the Odelsting. \>

Fjalstad: Den ærende representant hr. Bondes angrep på proposisjonen og innstillingen må hvile på en total misforståelse av hvad lovutkastet går ut på. Forholdet er nemlig det at ifølge proposisjonen og den enstemmige innstilling vil der ikke være anledning til seksualinngrep
Fjalstad: The honorable representative Bonde's attack on the bill and its recommendation must rest on a total misunderstanding of what the draft law sets out to do. The case is that according to the bill and the unanaimous recommendation there will not be permission to sterilize a normal 
like overfor normale personer, selv om de er sedlighetsforbryterer, med mindre de selv samtykker i det. Og hvad sinnssyke personer og personer med sterkt nedsatt tilregnelighet angår kreves det samtykke av vergen. Forslaget bygger på frivillighetsprincippet. Jeg skal ikke si mer om saken i sin almindelighet. Jeg forbeholder mig å komme tilbake til det spørsmål som det har vært en del diskusjon om i komiteen, når vi kommer til den spesielle paragraf. Jeg vil bare her ha fremholdt at det må være misforståelse av hvad loven går ut på, som ligger til grunn for representanten Bondes angrep på proposisjonen. (page 160)

Statsråd Sunde: Efter det som er uttalt av de to siste ærnde talere, kan jeg fatte mig i den største korthet. Hr. Bonde talte om slett lovforbedredelse. Det forekommer mig at man før man bruker den slags uttrykk, burde bemøie sig med å lese iallfall selve lovforslaget og helst også preposisjonen.

Bonde: Det var typisk å høre hr. Bonnevies uttalelser, hvor han gjorde sig til talsmann for at de meninger som jeg forfekter, kunde det ikke tas hensyn til fordi de kom fra en enkelt man, mens det stod en enstemmelig komitéinnstilling mot mig. Det er jo så her i Stortinget at den individuelle mening teller ikke, det er bare partimeningen. Og når jeg da representerer et helt parti, vil jeg sette stor pris på om det blev tatt hensyn til den mening som jeg forfekter. Det er så at ingen kan benekte den ting at der i utredningen vedrørende dette lovforslag ikke er tatt hensyn til de nye resultater som man gjennem den nye psykologi og psykoanalysen er kommet til ut over verden, det kan statsråden ikke benekte, det kan ingen benekte. Og da har jeg rett til å karakterisere tingen sådan som jeg har gjort, fordi jeg mener det er et vesentlig punkt i tingen. Og jeg mener det er i høi grad påkrevd av Odelstinget å vise den største forsiktighet like overfor de voldelige inngrep som her er antydet like overfor individet. Og man kan heller ikke komme forbi den ting at man retter baker for smed, når man tar fatt på individet utelukkende for de ting som også samfundet har den største skyld for. Jeg vil så innstendig jeg kan, henstille til Odelstinget at det ikke vedtar denne person even if they are sexual criminals, unless they consent to it. And as far as concerns mentally ill people and people with gravely diminished responsibilities, consent of a guardian would be required. The bill builds on the principle of voluntary action. I won't say anything more about the case in general. I reserve the right to come back to the question that has been discussed in the committee when we come to that specific paragraph. I want only here to call attention to the fact that there must be a misunderstanding on what the law sets out to do which is the basis for Represenetative Bonde's attack on the bill. (page 160)

Minister Sunde: After what has been expressed by the last two honerable speakers I will be very brief. Mr. Bonde spoke about a poor preparation of the law. It strikes me that before one uses this type of language, one should take the trouble, in any case, to read the bill that has been suggested and preferably also the report itself.

Bonde: It was typical to hear Mr. Bonnevie's words where he made himself the spokesman and claimed the opinions that I defend and which could not be taken into consideration becaue it comes from an individual man while an unanimous committee recommendation stood against me. It is like this here in the Storting, that an individual opinion means nothing and that there is only the party opinion. As I represent a whole party I would greatly appreciate it if you consider - the opinion that I am putting forward. It is true that nobody can deny that, in the way that this bill has been prepared, the new results that one has seen from the new psychology and psychological analysis from all over the world has not been paid attention to; the Cabinet Minister cannot deny this, noone can deny it. And then consequently, I have the right to characterize the thing just as I have done, because I believe it is an essential point in that thing. And I believe it is to a high degree necessary for the Odelsting to show the greatest care in relation to such a violent intervention presumed to directly affect the individual. Nor should we forget whereby one makesthe innocent suffer for the guilty, when one concentrates exclusively on the individual for the things which society also has the greatest guilt for. I want to 
skjebnesvangre lov nu iår, men nærmere overveier spørsmålet til neste år. propose to the Odelsting as urgently as I can that it should not pass this fateful law now this year but more thoroughly review the question next year.

Bjørnson: Vi i komiteen blev fra hr. Bonde bebreidet at vi hadde ikke fremlagt denne sak i dens hele dybde, kan jeg vel si. Jeg vil sannelig til hr. Bonde selv komme med adskillige bebreidelser. Han kommer i et langt, oratorisk innlegg og skal angripe oss, uten at han vitterlig har lest loven. Det fremgår da tydelig hvad han sa. Han uttalte at samfundet vil gå frem med vold. Ikke på nogen måte, hr. Bonde! Det står til individet selv å bestemme hvor vidt han vil la sig seksualoperere, og er individet slik at han ikke har sin fulle åndsfullkommenhet, så har han en kurator eller en verge som skal bestemme for ham. Det står i vår lov. Så bebreidet han oss at vi ikke har tatt hensyn til den moderne linje, som hr. Bonde taler om. Det viser mig atter hvor lite hr. Bonde har lest denne lov. Hvis han ser efter i §4, så står det at medisinaldirektøren eller i tilfelle det sakkyndige råd bestemmer seksualinngrepets art. Det er med andre ord efter denne lov intet $i$ veien for at man kan gå inn på den linje som hr. Bonde mener man skal redde samfundet efter.

Denne sak er av en overordentlig stor betydning. Hvis man har lest all den litteratur som er fremkommet om denne sak, vil man komme til det. Det viser sig i allfall in Danmark, hvor man har statistikk både over lovens virkninger, likesom man også har statistikk over fødselsprocenten innen de forskjellige leire, at mens fødeselsprocenten går ned hos de levedyktige individer, de ansvarlige familier, så har den steget i en voldsom grad nettop hos de defekte familier, og for å kunne være med og råde bot på dette og få en sterk slekt er det heller ikke minst at man har gått til denne lov, en lov som har gått sin seiersgang over hele verden og som jeg ikke tviler på at Odelstinget vil se berettigelsen av. La så samfundpartiet få lov til å stå der! Det er ikke første gang jeg kjemper mot den reaksjonære linje i dette partis program under navn av en frihet som vi andre ikke forstår.
Bjørnson: I suppose I can say that Mr. Bonde has criticized us in the committee for not having discussed this law in all its depth. I will truthfully criticize Mr. Bonde himself with devisive criticism. He comes here with a long, oratorical speech and attacks us, obviously without having read the law. This is evident from what he has said. He said that society would use violence. By no means, Mr. Bonde! It is for the individual himself to decide whether he wants to allow these sexual operations or not and if it is an individual who does not have full mental comprehension then he has a social worker or a guardian who can decide for him. That is included in our law. Then hecriticized $r$ us that we have not paid attention to the modern line - as Mr. Bonde speaks about. It shows me again how little Mr. Bonde has read this law. If he looks carefully at $\S 4$ it says that either the Medical Director or, if that's the case, an expert committee, decides the nature of the operation. There is, in other words, nothing in this law that prohibits the line that Mr. Bonde believes would save society.

This case has extraordinarily far-reaching implications. If one has read all of the literature that has come outon the issue, one would realize that this can be shown in Denmark at any rate where one has both statistics about the inplementation of the law, and about the birth rate in different categorie; that while the birth rate decreases in the homes of healthy individuals, the responsible families, the birth rate has increased to a horrible extent exactly in the defective families and, in order to get a strong stock, it is not least in order to repair this and to achieve what we have proposed this law, that has gone in a triumphant march around the world and which I have no doubt the Odelsting will see the justification for. Let the Samfundsparti just stand there! This is not the first time that I have fought against the reactionary line in that party's program that goes under the name of a freedom that the rest of us can't understand. 
Bonnevie: Hr. Bonde har ennu ikke kunnet overbevise mig om at han overhodet har lest proposisjonen og innstillingen. Det er denne og lignende grunner som gjør at jeg ikke kan tillegge hans ord særlig vekt, ikke fordi de kommer fra ham eller samfundspartiet. Hadde hr. Bonde lest proposisjonen og innstillingen og ennu mer de utrykte dokumenter, vilde han kunnet se at det er vårt lands første psykologer, bl.a. menn som professor Ragner Vogt og overlæge Scharffenberg, som har arbei- (page 161) det med i denne sak. Den er utredet av folk som kjenner sakens både psykologiske og fysiske side.
Bonnevie: Mr. Bonde has still not convinced me that he has read the bill and the report at all. It is because of this and the similar reasons that I can't give his words any special weight not because they come from him or from the Samfundsparti. Had Mr. Bonde read the bill and the recommendations in the report and, additionally, the documents that were not printed, then he would have been able to see that they are from our country's foremost psychologist, among others, Professor Ragner Vogt and Medical Director Scharffenberg, who have work- (page 161) ed on this bill. It has been worked on by people who know both the psychological and the physical dimensions of the proposal.

Presidenten: Hr. Bonde har havt ordet tvo gonger President: Mr. Bonde has spoken two times and og har order til ein stutt merknad.

Bonde: Jeg vil bare gjøre opmerksom på at jeg selvføgelig har lest proposisjonen og dens forarbeider meget inngående, og jeg behandler tingen ganske enkelt ut den ånd og den mening som ligger i loven, og som fører til kastrering av sedelighetsforbryteren som mål. Jeg vil bare sette fingeren på at det videnskapelig sett er erkjent nu at det er andre måter å løse det hovedspørsmål på som loven tar sikte på å løse, der er andre måter enn ved voldelig inngrep på individet, og ut fra den forutsetning mener jeg at man skal være forsiktig med å vedta en så brutal lov som denne. Når hr. Bonnevie nevnte at det har vært forelagt psykologer som doktor Vogt og doktor Scharffenberg, så vil jeg bare gjøre opmerksom på at den psykologi som de representerer ikke har noget med den psykologiske gren å gjøre som jeg tenker på, nemlig psykoanalysen, og jeg fastholder at lovforslaget ikke er forberedt under hensyntagen til det som faktisk idag foreligger på psykolgiens videnskaplige område. has the floor for one closing remark.

Bonde: I only want to point out that of course I have obviously read the bill and the prepatory works and have studied it very carefully and I treat this thing quite simply from the spirit and the meaning that is in the law and which leads to the castration of the sexual criminal as its goal. I wantonly to point out that, scientifically speaking, it is now acknowledged that there are other methods to solve this main question that this law intends to solve, there are other means than such a violent intrusion on the individual, and from this assumption I believe that one should be careful about approving such a brutal law as this. When Mr. Bonnevie mentioned that the bill was submitted to psychologists such as Dr. Vogt and Dr. Sharffenberg, I will only point out that the psychology that they represent has nothing to do with the branch of psychology that lam thinking about, namely psychoanalysis, and I maintain that the proposed bill was not prepared with attention to what actually is being discussed in the scientific areas of psychology.

Presidenten: $\mathrm{Hr}$. Bonde har sett fram eit utsetjingsframlegg som ein må avgjera fyrr ein går på tilrådinga. Framlegget lyder slik: « 0t. President: Mr. Bonde has put forward a suggestion for postponment that must be decided before the proposal. The proposal is as follows: prp. Nr. 17 for 1934 tas ikke under behandlingen « Ot.prop. nr. 17 for 1934 is not taken under av inneværende års Odelsting. \> consideration by this year's Odelsting. »

\section{Voting:}

The suggestion from Bonde was rejected receiving only one vote. 
Nemnda hadd tilrådt Odelstinget å fatte følgende The Committee had proposed that the Odelsting should take up the following

Beslutning til lov om adgang til sterilisering m.v. Resolution regarding the law allowing access to sterilization.

$\S 1$ $\S 1$

En operasjon eller annen behandling som til An operation or other treatment which is intended sikter å opheve en persons forplantningsevne eller kjønnsdrift (seksualinngrep) kan foretas såfremt tillatelse innhentes efter reglene i denne lov. to annul the reproductive ability or the sex drive of a person can be performed so long as permission is provide according to the rules set out in this law.

Tillatelse kreves dog ikke når inngrep av medisinke eller andre grunner er rettmessig efter rettsregler utenfor denne lov.

Permission of this type is not required when the procedure, due to medical or other reasons, is lawful according to the rules set out in other laws.

§2 \$2

Tillatelse efter $\S 1$ gis av medisinaldirectøren. Permission according to $\S 1$ may be given by the Medical Director.

Gjelder inngrepet en person som er mindreårig If the procedure concerns a person who is a minor eller sinnssyk eller som har mangelfult utviklede or who is mentally ill or lacks mental developsjelsevner, gis tillatelsen av et sakkyndig råd, som skal bestå av medisinaldirektøren som formann og 4 andre medlemmer, opnevnet av Kongen. Blandt mendlemmene skal det være minst en kvinne, en dommer og 2 læger. ment, permission must be given by an expert panel, consisting of the Medical Director as Chairman and four other members, appointed by the King. Among the other members there shall be at least one woman, one judge and two doctors.

$\S 3$ $\S 3$

På en person som selv begjærer det, kan et seksualinngrep tillates foretatt når begjæringen har en aktverdi grunn. Er han under 21 år eller sinnssyk eller er hans åndsevner mangelfullt utviklet kreves også samtykke fra vergen eller den i §6 nevnte kurator.

If a person himself makes an application, the sexual intervention can be permitted, carried out when the reason is acceptable. If he is nder 21 years of age or mentally ill or has a lack of mental development, approval is needed from the guardian or the social worker as mentioned in $\S 6$.

$\S 4$ $\S 4$

På sinnssyke og personer med særlig mangelfullt Sexual intervention on the mentally ill and utviklede sjelsevner kan sesksualinngrep tillates foretatt efter begjæring fra verge eller den i §6 nevnte kurator, når det ikke er håp om helbredelse eller vesentlig bedring og det er grunn til å anta at vedkommende ikke vil bli i stand til ved eget arbeide å sørge for sig og avkom, eller at en sykelig sjelstilstand eller en betydelig legemlig mangel vilde bli overført på avkom, eller at han på grunn av en abnorm kjønnsdrift vil begå sedelighetsforbrytelser. persons with a lack of mental development can be permitted, carried out at the request of the guardian or the social worker mentioned in $\S 6$ when there is no hope of recovery or essential improvement and there is reason to presume that the person will not be able to work in order to care for himself or his offspring, or that the mental condition or the serious physical defect will be conveyed to the next generation, or, that due to his abnormal sex urge, he will commit sexual crimes. 
Begjæring om seksualinngrep kan i slike tilfelle også fremsettes av politimesteren i det distrikt hvor vedkommende bor; har vedkommende ikke fast bopel, kan den fremsettes av politimesterin i distrikt hvor han opholder sig. Er vedkommende anbragt i fengsel eller tvangsarbeidershus eller $\mathrm{i}$ pleie - eller opdragelsesanstalt, som står under offentlig tilsyn, kan begjæring tillike frem (page 162) settes av anstaltens bestyrer. I begge de her nevnte tillfelle kreves dessuten samtykke fra verge eller kurator.
A request for sexual intervention can, in such a case, also be proposed by the Police Chief of the district where the person lives; if the person has no stable residence, then the Chief of Police from the district where the person is currently living can propose it. If the person is located in a prison or in a work house or in care - or in a closed educational institution which is under administrative supervision, the request can also be made by the supervisor of the institution. In bothcases mentioned here, a guardian or a social worker must also approve the request.

\section{$\S 5$}

$\S 5$ The Medical Director or, when elevant, the expert panel, can decide the nature of the sexual intervention, where the intrusion shall take place and who shall perform it. Normally, this can be undertaken in a public or a county hospital, or in a private hospital which has been approved by the panel for this purpose.

\section{$\S 6$}

$\S 6$

Hvis en som er sinnssyk eller har mangelfullt utviklede sjelsevner, ikke er umyndig, skal herreds - eller byretten efter begjæring av medisinaldirektøren opnevne en kurator når det opstår spørsmål om seksualinngrep efter $\S \S 3$ og 4. Det sakkyndige råd kan beslutte at det for en som umyndig, av herreds - eller byretten skal opnevnes en kurator, såfremt vergen ikke antas skikket til å avgi erklæring om seksualinngrep.

Denne beslutning av de sakkyndige råd kan under en frist av14 dager av vergen innankes for vedkommende department.

If a request has been received or behalf of a person who is mentally ill or lacks mental development but who is not a minor, then the district court shall, at the request of the Medical Director, appoint a social worker. If a request has been received under $\S \S 3$ and 4, the expert panel can decide that there should be named a social worker for one who is a minor, if the minor's guardian is not seen as competent to represent the minor for a sexual intervention.

This decision of the expert panel can, within a deadline of 14 days, be appealed to the appropriate Ministry.

\section{$\S 7$} $\S 7$

Enhver som i medhold av denne lov får befatning med steriliseringssaker, plikter å bevare taushet overfor uvedkommende med hensyn til hvad han i stillings medfør har fått kjennskap til. Over tredelser av taushetsplikten straffes med bøter, hvor ikke strengere straff følger av andre lovbestemmelser.
Pursuant to this law, everyone who has dealings with sterilization cases has a duty of silence regarding the persons involved in relation to the knowledge that he received in the undertaking of his job. Breaches of this duty of silence will be punished with fines if there is no stronger punishment under other laws. 
$\S 8$

$\S 8$

Før det blir gitt samtykke til seksualinngrep på en gift person, skal ektefellen så vidt mulig få

Before consent may be given for sexual intervention on a married person, the marriage partner shall, as far as possible, be given access to be heard on the request.

$\S 9$ $\S 9$

Kongen gir de nærmere regler som ansees nødvendige til gjennomførelsen av denne lov.

The King will further spedify the rules which are presumed to be necessary for the xecution of the law.

Røysting:

Voting:

Tilrådinga frå nemnda vart vedtaken mot 1 røyst. The advice from the Committee was taken against one vote.

Etter framlagg frå presidenten vart samrøystes vedteke:

After a suggestion from the President an unanimous vote was taken:

Lovvedtaket vert sendt Lagtinget. The law was sent to the Lagting.

* Page 573, "arbeidsdyktige" has been translated as "able-bodied workers" although it has the connotation of "productive" as well as "capable."

** Page 578, "seksualinngrep" has been translated as "sexual intervention", i.e. castration.

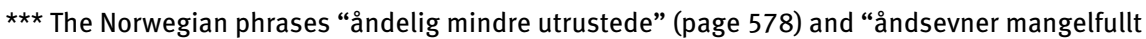
utviklet" (page 585) have been translated as "mentally less endowed" and "lack of mental development." In the social science language of the earlier $20^{\text {th }}$ century, this might have been translated as "mentally retarded" and in the language of the late $20^{\text {th }}$ and early $21^{\text {st }}$ century this is a reference to those that are "developmentally delayed."

\subsection{Appendix F - Comstock Act}

An Act for the Suppression of Trade in, and Circulation of, Obscene Literature and Articles of Immoral Use

Be it enacted by the State and House of Representatives of the United States of America in Congress ssembled, That whoever, within that whoever, within the District of Columbia, or either of the Territories, or other place within the exclusive jurisdiction of the United States, shall sell, or offer to sell, or shall give away, or offer to give away, or shall have in his or her possession with intent to sell or give away, any obscene or indecent book, pamphlet, paper, advertisement, drawing, lithograph, engraving, wood-cut, daguerreotype, photograph, stereoscopic picture, model, cast, instrument, or other article for indecent or immoral nature, or any article or medicine for the prevention of conception, or for causing abortion except on a prescription of a physician in good standing given in good faith, or shall advertise the same for sale, or shall write or print, or cause to be written or printed, any card, circular, book, pamphlet, advertisement, or notice of any kind, stating when, where, how, or of whom, or by what means, any of the said obscene or indecent articles, or those hereinbefore 
mentioned, can be purchased or obtained, or shall manufacture, draw, or expose to have sold or exposed, or shall print any such article, shall, on conviction thereof, be imprisoned at hard labor for not less than six months nor more than five years for each offense, or fined not less than $\$ 100$. nor more than $\$ 2,000$. with costs of court.

Sec. 2. That section one hundred and forty-eight of the act to revise, consolidate, and amend the statutes relating to the Post Office Department, approved June 8, 1872, be amended to read as follows:

Sec. 148. That no obscene, lewd, or lascivious book, pamphlet, picture, paper, print, or other publication of an indecent character, or any article or thing designed or intended for the prevention of conception or procuring of abortion, nor any article or thing intended or adapted for any indecent or immoral use or nature, nor any written or printed card, circular, book pamphlet, advertisement, or notice of any kind giving information, directly or indirectly, where, or how, or of whom, or by what means either of the things before mentioned may be obtained or made, nor any letter upon the envelope of which, or postal cared upon which indecent or scurrilous epithets may be written or printed, shall be carried in the mail; and any person who shall knowingly deposit, or case to be deposited, for mailing or delivery any of the hereinbefore mentioned articles or things, or any notice or paper containing any advertisement relating to the aforesaid articles or things, and any person who, in pursuance of any plan or scheme for disposing of any of the hereinbefore mentioned articles or things, shall take or cause to be taken from the mail any such letter or package, shall be deemed guilty of a misdemeanor, and, on conviction thereof, shall, for every offense, be fined not less that $\$ 100$ nor more that $\$ 5,000$, or imprisoned at hard labor not less than one year nor more than ten years, or both, in the discretion of the judge.”

Sec. 3. That all persons are prohibited from importing into the United States, from any foreign county, any of the hereinbefore mentioned articles or things, except the drugs here-inbefore mentioned when imported in bulk, and not put up for any of the purposes before mentioned, under a penalty of $\$ 1,000$ for each importation, to be imposed upon due conviction of such offense; and all such prohibited articles in the course of importation shall be seized by the officer of customs and condemned and destroyed.

Sec. 4. That whoever, being an officer, agent, or employee of the Government of the United States, shall knowingly aid or abet any person engaged in any violation of this act, shall be deemed guilty of a misdemeanor, and, on conviction thereof, shall, for every offense, be punished as provided in section two of this act.

Sec. 5. That any judge of any district or circuit court of the United States before whom complaint of any violation of this act shall be made, supported by oath or affirma- 
tion founded on knowledge or belief, may issue, conformably to the Constitution, a warrant directed to the marshal, or any deputy marshal, in the proper district, directing him to search for, seize, and take possession of any such obscene or indecent books, papers, articles, or things, and to make due and immediate return thereof, to the end that the same may be condemned and destroyed by proceedings, which shall be conducted in the same manner as other proceedings in case of municipal seizure.

Comstock Law Excerpted from U.S. v. One Package, 86 F.2d 737, 739 (1936).

\subsection{Appendix G - Ethnic and Religious data for New Haven, 1939}

\section{Ethnicity and Religion in New Haven, 1939}

By its own count, the Roman Catholic Diocese of Hartford Connecticut had 603,467 members in 1929; this population had essentially doubled since the end of Bishop Michael Tierney's term in 1908 when the population had been 325,000. ${ }^{1321}$ The economic growth of the Hartford Diocese can be tracked in the following chart since, in the main; it was voluntary contributions that built the institutions.

Table 8.2: Percent change, Catholic personnel and institutions, 1844-1929 Diocese of Hartford, Connecticut (Numbers positive unless noted.)

\begin{tabular}{|c|c|c|c|c|c|c|c|c|c|}
\hline$\frac{\breve{0}}{\frac{0}{0}}$ & $\begin{array}{l}\frac{5}{0} \\
\frac{0}{0} \\
\frac{0}{0} \\
0\end{array}$ & 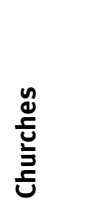 & $\begin{array}{l}\stackrel{n}{0} \\
\frac{0}{n} \\
\frac{\mathscr{L}}{\Sigma}\end{array}$ & 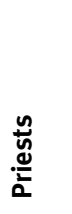 & $\begin{array}{l}n \\
\frac{n}{\circ} \\
\frac{\grave{L}}{n} \\
\end{array}$ & $\frac{\mathscr{a}}{\stackrel{0}{o b}}$ & 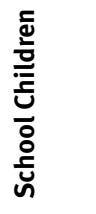 & 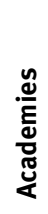 & 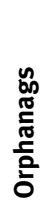 \\
\hline $\begin{array}{l}\text { William Tyler } \\
(1844-1849)\end{array}$ & 15,000 & 13 & 0 & 8 & 0 & 0 & 0 & 0 & 0 \\
\hline $\begin{array}{l}\text { Bernard O'Reilly } \\
(1850-1856)\end{array}$ & 35,000 & 22 & 16 & 22 & 10 & 41 & 2,500 & 2 & 2 \\
\hline $\begin{array}{l}\text { Per Cent Increase } \\
(1849-1856)\end{array}$ & 133.3 & 69.2 & & 175 & & & & & \\
\hline $\begin{array}{l}\text { Francis P- MacFarland } \\
(1858-1874)\end{array}$ & 140,000 & 76 & 69 & 77 & 18 & 100 & 8,000 & 2 & 2 \\
\hline $\begin{array}{l}\text { Per Cent Increase } \\
(1856-1874)\end{array}$ & 300 & 245.5 & 331.3 & 250 & 80 & 143.9 & 220 & 0 & 0 \\
\hline
\end{tabular}

1321 Right Reverend Thomas S. Duggan, Catholic Church in Connecticut, Centennial Edition (New York City: The States History Company: 1930), 608. 
continued Table 8.2 Percent change, Catholic personnel and institutions, 1844-1929 Diocese of Hartford, Connecticut (Numbers positive unless noted.)

\begin{tabular}{|c|c|c|c|c|c|c|c|c|c|}
\hline$\frac{\dddot{0}}{\frac{0}{0}}$ & 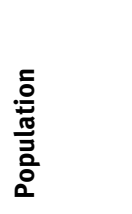 & 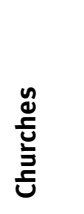 & $\frac{\mathscr{n}}{\stackrel{0}{n}}$ & $\begin{array}{l}\frac{n}{\tilde{y}} \\
\frac{\underline{x}}{2} \\
\end{array}$ & $\begin{array}{l}\frac{n}{\circ} \\
\stackrel{ }{\check{L}} \\
\text { un }\end{array}$ & $\frac{\mathscr{c}}{\stackrel{0}{0}}$ & 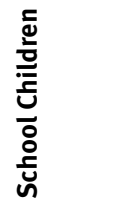 & 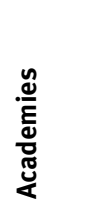 & 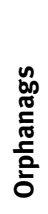 \\
\hline $\begin{array}{l}\text { Thos. Galberry } \\
(1876-1878)\end{array}$ & 150,000 & 83 & 74 & 83 & 23 & 160 & 10,100 & 3 & 3 \\
\hline $\begin{array}{l}\text { Per Cent Increase } \\
(1874-1878)\end{array}$ & 7.1 & 9.2 & 7.2 & 7.8 & 27.8 & 60 & 26.3 & 50 & 50 \\
\hline $\begin{array}{l}\text { Lawrence McMahon } \\
\text { (1879-1893) }\end{array}$ & 250,000 & 96 & 54 & 180 & 40 & 485 & 16,000 & 3 & 3 \\
\hline $\begin{array}{l}\text { Per Cent Increase } \\
(1878-1893)\end{array}$ & 66.7 & 15.7 & -27 & 116.9 & 73.9 & 203.1 & 58.4 & 0 & 0 \\
\hline $\begin{array}{l}\text { Michael Tierney } \\
(1893-1908)\end{array}$ & 325,000 & 156 & 51 & 280 & 69 & 1,115 & 30,275 & 3 & 3 \\
\hline $\begin{array}{l}\text { Per Cent Increase } \\
(1893-1908)\end{array}$ & 30 & 62.5 & -5.6 & 55.6 & 72.5 & 129.9 & 89.2 & 0 & 0 \\
\hline $\begin{array}{l}\text { John J. Nilan } \\
(1910-)\end{array}$ & 603,467 & 235 & 51 & 546 & 101 & 2,197 & 48,293 & 8 & 3 \\
\hline $\begin{array}{l}\text { Per Cent Increase } \\
(1908-1929)\end{array}$ & 86.3 & 50.6 & 0 & 95 & 46.6 & 96.9 & 59.5 & 166.7 & 0 \\
\hline
\end{tabular}

\subsection{Appendix H - Waterbury, Connecticut Roman Catholic Church Proclamation, 11 June 1939}

Proclamation read at all Roman Catholic Churches in Waterbury, Connecticut on 11 June 1939.

Whereas, it is the teaching of the Catholic church that birth control is contrary to the natural law and therefore immoral, and

Whereas, it is forbidden by statue law to disseminate birth control information for any reason whatsoever or in any circumstance, and

Whereas, it has been brought to our attention that a so-called birth control clinic, sometimes called a maternal health center, is existing in Waterbury as admitted by the superintendent of Chase Dispensary, according to the papers, therefore be it 
Resolved, that this association go on record as being unalterably opposed to the existence of such a clinic in our city and we hereby urge our Catholic people to avoid contact with it and we hereby publicly call the attention for the public prosecutors to its existence and demand that they investigate and if necessary prosecute to the full extent of the law. ${ }^{1322}$

\subsection{Appendix I - Demurrer to Criminal Information}

The following is a detailed account of the legal maneuvering in the Chase Case.

A number of counts of violation of the 1879 Connecticut anti-contraception statute were filed against the three who all pled "not guilty.” J. Warren Upson and Lawrence L. Lewis represented the three defendants on Friday, June 23. The two doctors were described as "young doctors"; Nelson was 30 and Goodrich was 29 years old. McTernan was 40 years old. After Lewis argued for parole into his custody of the three, Judge Wynne commented that the information about the case was "sketchy" but he believed all three to be connected in some professional capacity with the clinic. Wynne also commented that he thought the case was about "religious, moral or ethical" differences of opinion and since the three probably thought they had a right to do what they did, he could see no reason for the posting of a $\$ 500.00$ bond. Nelson was charged with three counts of giving birth control assistance, on 17 January 1939, to a 27-yearold married woman, on 18 October 1939 to a 21 year old married woman and on 27 February 1939 to a 27 year old woman. Goodrich and McTernan were each charged with three counts also, of providing birth control information on 31 January 1939 to a 22 year old married woman, on 8 November 1938 to a 23 year old married woman and on 22 November 1938 to a 22 year old married woman. The penalty for violation of the statues was at least 60 days in jail with the possibility of up to one year in jail and a $\$ 50.00$ fine or both. The trial would be held in September although Lewis retained, on the record, the right to withdraw the "not guilty" pleas.

Roman Catholic lay organizations soon became involved in the affair. The Notre Dame Alumni Association passed a resolution in support of "the stand taken by priests of the city" in which the clinic was condemned. ${ }^{1323}$ The Knights of Columbus ("KOC") would also get involved. ${ }^{1324}$ Once organized, they did the bidding of the clergy on

1322 John W. Johnson, Griswold v. Connecticut: the Constitutional Right of Privacy (Lawrence: University Press of Kansas, 2005), p. 22.

1323 Waterbury Democrat, 14 June 1939, p. 1. Again and again the Democrat implicitly asks the Bishop to take action saying that he "may" issue a statement. Also, the Democrat - again and again - wrote about the possibility of a need for a statewide investigation, as if it were advocating this.

$1324 \mathrm{http} / / /$ www.archdiceseofhartford.org/archdiocesehistory.htm, accessed on January 7, 2008. Father Michael J. McGivney had originally founded that group on 29 March 1882 in the basement of St. Mary's Church in New Haven, the town next door to Waterbury. McGivney, now a candidate for sainthood, originally organized the group so that it would "prevent our people form entering Secret 
many fronts over the years. ${ }^{1325}$ But the KOC was also a response to "strong anti-foreigner" sentiment among New Englanders. New Haven had attracted a large number of immigrants because of the jobs in railroads and industry there and competition with "nativist" New Englanders was a problem. ${ }^{1326}$ Earlier, in the 1850s, the "KnowNothing" political party had been organized; the majority of its members joined what became the modern day Republican Party in the 1860s. This nativist party actively and enthusiastically - worked against the interests of immigrants, into the twentieth century. The Knights of Columbus, while providing solicarity for Catholic men and a buffer for xenophobia also carried out the wishes, the political wishes, of the hierarchy in whichever diocese they existed.

On Thursday, 29 June 1939, the lead story for the Waterbury Democrat was the Chase Dispensary Case. Splayed across the front of the paper was the headline, "Demurrer Filed in Alleged Birth Control Case" along with "Attorneys For Accused Physicians, Nurse Say Law Unconstitutional" below. ${ }^{1327}$ J. Warren Upson had filed a demurrer on behalf of the three defendants and made a brief statement to that effect before Judge Kenneth Wynne. ${ }^{1328}$ State's attorney William B. Fitzgerald had filed an amended complaint, adding the fact that Goodrich and Nelson were "duly licensed physicians" and the McTerhan was a "duly qualified nurse" thereby, according to the Democrat, making the case "a real test." Upson and Fitzgerald agreed to the defense brief by 25 July and the state's answer on 15 August. The trial would not be held until the September criminal term. ${ }^{1329}$

Upson's statement to the Court settled the issue of whether or not the Chase Dispensary was a birth control clinic. He said

Both doctors are engaged in private practice, and voluntarily gave their services to the birth control clinic at the Chase dispensary, which is the outpatient department of the Waterbury Hospital. ${ }^{1330}$

Societies by offering the same if not better advantages to our members" and to unite the men of our faith throughout the diocese of Hartford, that we may gain strength to aid each other in time of sickness; to provide for decent burial, and to render pecuniary assistance to the families of deceased members. 1325 The Knights of Columbus continue to be used by clergy for support of various political issues that implicate the Church. As mentioned above in footnote 1726, in Washington, D.C. in summer, 2006, the KOC tried to organize Catholics to write in support of the "Defense of the Family Act" that defined marriage as an institution composed of one female and one male. Their material was inserted into Our Lady of Lourdes (Bethesda, Maryland) weekly parish bulletin. Please see: http://religousmovements.lib.birginia.edu/Knights.html. Also, please see: Christopher J. Kauffman, Faith and Fraternalism (New York: Harper \& Row Publishers, 1982).

1326 Ibid.

1327 Waterbury Democrat, June 29, 1939, 1. Flush left.

1328 A "demurrer" was essentially an answer to a complaint which says that the defendants acknowledge everything the complaint alleges, makes legal arguments and then asks, in essence, "so where is the crime/harm?” This document is reprinted in Appendix IX at page 580.

1329 Ibid.

1330 Ibid. 
In the defense demurrer $\S 6246$ of the Connecticut General Statutes was alleged to be unconstitutional because it interfered with the individual liberties of state citizens as well as being a violation of the due process clause of the federal Constitution. It "sets no reasonably precise standards of guilt and in that it sets forth no maximum fine." The demurrer also alleged that the law did not make exceptions for doctors engaged in trying to save the life of their clients or in protecting their health. The state's warrant was "fatally defective" in that the accused may have given birth control information "for reasons of health", as opposed to only for contraception. ${ }^{1331}$ In a rare move, the Democrat printed the entire text of the demurrer for the public to read. ${ }^{1332}$

On Monday, 3 July 1939, Warren Upson was back in Superior Court before Judge Frank P. McEvoy (1878-1945) arguing a motion for dismissal of the entire case. ${ }^{133}$ McEvoy had been born in Waterbury. Both of his parents died in his early childhood and so he was sent to live with an uncle, Reverend Patrick P. Lawlor, then the pastor of St. Mary's (Catholic) Church on Hillhouse Avenue. ${ }^{1334}$ He graduated from Yale School of Law in 1907 where he was editor of the Yale Law Review. He had worked for years in a partnership with Francis P. Guilfoile. ${ }^{1335}$ In 1930 he was appointed by Republican governor, John H. Trumull (1925-1931), to fill the vacancy created by the death of Superior Court Judge L.P. Waldo Marvin, although McEvoy was a member of the Democratic Party. ${ }^{1336}$ At the time of this hearing, he was a member of Blessed Sacrament Church in Waterbury, the sponsor of a Boy Scout troop as well as a member of the Holy Name Society at that church. As his obituary read,

\footnotetext{
Partly as a result of his early life with his uncle in New Haven, but principally of his innate religious convictions, he was a devout communicant of the Roman Catholic church....It is hardly possible to conceive of a layman more thoroughly imbued with this religion than Judge McEvoy, or more devoted to is principles. And yet he was no bigot. ${ }^{1337}$
}

If this were true, it might be worthwhile asking why he did not recuse himself from the case. ${ }^{1338}$ That Upson did not ask McEvoy to recuse himself is clear enough; this was to be a test case.

1331 Ibid.

1332 Waterbury Democrat, June 29, 1939, 4.

1333 Waterbury Democrat, July 3, 1939, 1. Flush left.

1334 Please see Obituary Sketch of Frank P. McEvoy at http://www.cslib.org/memorials/mcevoyf. $\underline{\mathrm{htm}}$, last accessed on January 7, 2008.

1335 Although I have been undable to confirm this, Guilfoile may have been a brother to McEvoy's wife, Gertrude.

$1336 \mathrm{Ibid}$. Guilfoile would later become counsel to the city of Waterbury and its Mayor for four terms. 1337 Ibid., 3.

1338 "Recusal" is a procedure whereby a Judge or attorney can remove him or herself fro a proceeding due to a conflict of interest. 
Upson argued a theory of "mens rea", that the state had produced no evidence that the items confiscated were "kept for the purpose of violating the criminal law." McEvoy chose not to make a ruling on the motion and ordered that the issue be briefed; the defense brief was due on July 25 and the state's brief on August 15, the same days as ordered in Judge Wynne's Court. William B. Fitzgerald argued that he was prepared to prove "beyond a reasonable doubt" the intent to commit a crime citing to the North Shore Mothers Health Office of Salem, Massachusetts case the Margaret Sanger case of New York.

On a desk in the courtroom that July day were "several bagsful" of items as well as booklets that had been seized by the police in their raid of the Chase Dispensary. ${ }^{1339}$ In his rebuttal, Fitzgerald produced a stipulation signed by both himself and Upson that the articles in the bags belonged to the Connecticut Birth Control League and the Waterbury Maternal Health Center. Exactly how the issue came before the Court is unclear but at some point, the destruction of the articles came into issue. It may be that the issue is intentionally unclear as Mr. Fitzgerald had to change is position in mid-hearing. Upson is reported as arguing against the state since it asked for a condemnation order under Section 6441, saying the state had not met its burden of proof. This fact is buried on page 4 after Fitzgerald is reported, on page 1, as saying the items would be needed for the trial. It might have been that Fitzgerald anticipated pleas of guilty and submitted the order for destruction prematurely. Or, Fitzgerald was not familiar with criminal trials and the need for the items to be admitted into evidence subject to defense challenges to the "chain of evidence."

Upson went on to give his argument in full, eventually pointing out that there was a split of opinion in the United States between various jurisdictions on the legal issue; the prosecution relied on a Massachusetts case while the defense relied on several U.S. Court of Appeals cases. The state's attorney argued that Upson's constitutional claims were "not proper claims" in that they had been tried before and rejected. Fitzgerald brought up the case of Carolyn Gardner and other who operated the North Shore Mothers' Health Office at Salem, Massachusetts, all of whom who had been convicted on May 26, 1938. Their case had gone to the Massachusetts Supreme Court, where the Massacchusetts equivalent of the Comstock Act was upheld. Fitzgerald noted that Connecticut courts paid "respectful attention" to Massachusetts's courts. He also referred to Margaret Sanger saying the statute had been effect since 1879 and had to be "enforced, unless it is repealed."1340

The following is the text of the demurrer, which is identical in text except in the names of the accused:

1339 The items were consolidated and identified as one item.

1340 Waterbury Democrat, July 3, 1939, 1, 4. See Kenneth C. Sears, “Legal Control...” in Michigan Law Review, 44 (1946): 69 for reference to the North Shore case. 
STATE OF CONNECTICUT V. ROGER B. NELSON, Superior Court for New Haven County at Waterbury June 28, 1939.

\section{DEMURRER TO INFORMATION}

The defendant, having reserved his rights to plead to the information as on file, demurs to all counts of the information, and for reasons therefor, assigns the following:

I.

The information, and all three counts thereof, is based upon Section 6246 of the General Statutes of the State of Connecticut, and said Section is unconstitutional for the following reasons:

a. it constitutes an unconstitutional interference with the individual liberty of the citizens of the State of Connecticut;

b. it constitutes an unconstitutional interference with the individual liberty of the citizens of the sate of Connecticut under the provisions of the Constitution of the Untied States and the Constitution of the State of Connecticut;

c. it constitutes a deprivation of life, liberty and property without due process of law, under the provisions of Article 14 of the Amendments to the Constitution of the Untied States and under the provisions of Section 9 of Article First of the Constitution of Connecticut;

d. it fails to contain a reasonably precise standard of guilt;

e. it fails to fix minimum fine which may be imposed by the Court, and by virtue of the express provisions of the Statue, the Court might impose an unlimited fine, although the sole power to fix the limits of the fine or penalty reposes in the legislative branch of the government;

f. if the information correctly sets forth the crime under Section 6246 of the General statute, said Section is unconstitutional because it applies.

(1) where a married woman makes use of drugs, medical articles or instruments for the purposed of preventing conception upon the recommendation and advice of a physician;

(2) where a married woman makes uses drugs, medicinal articles or instruments for the purpose of preventing conception upon the advice of a physician under circumstances in which all physicians would agree that a pregnancy would jeopardize her life.

(3) where a married woman makes use of drugs, medicinal articles or instruments for the purpose of preventing conception upon the advice of a physician where for health reasons the use thereof is necessary for such purpose;

(4) where a married women makes use of drugs, medicinal articles or instruments for the purpose of preventing conception upon the advice of a physician where such contraceptive measures are necessary to protect and procure the best possible state of health and well being; 
g. inasmuch as the information does not except the right of the medical profession to prescribe the use of drugs, medicinal articles or instruments for the purpose of preventing conception where the life or health of a patient is at stake, the information, and each count thereof, is unconstitutional and said Section 6246, if it is so construed, without a clause protecting the right of any physician to prescribe drugs, medicinal articles or instruments for the purpose of preventing conception, is unconstitutional.

II.

If said Section 6246 is so construed as to protect the right of any physician to prescribe drugs, medicinal articles or instruments for the purpose of preventing conception, the information, and all three counts thereof, is fatally defective for the following reasons:

a. the information, and each count thereof, contains no allegation that the "married woman" has been charged with the violation of Section 6246 of the General statues or convicted thereof;

b. under the law of this State, an accessory to a crime cannot be charged and convicted as an accessory in the absence of the allegation and proof of the commission of the offense by the principal;

c. under the law of this State, an accessory to a crime cannot be charged and convicted as an accessory in the absence of the allegation and proof the conviction of the offence by the principal with which he is charged;

d. the information fails to charge a crime under the Statutes of the state of Connecticut;

e. because on its face the information fails to negative the fact that the physician caring for a married woman might have been advising the use of the contraceptive devices by reason of the physical condition of the patient or by reason of the fact that all physicians would agree that the life of the patient would be jeopardized if contraceptive devices were no furnished ore where, for the reasons of health and well being of the patient, contraceptive practices were necessary, the information, and each for the three counts thereof, is fatally defective;

f. the information, and all three counts thereof, contains an inadequate description of the crime, in that the date upon which the crime is supposed to have been committed is not set forth therein; and in that the place where the crime is supposed to have been committed is not set forth therein.

\section{DEFENDANT}

By J. WARREN UPSON L.L. LEWIS His Attorneys ${ }^{1341}$

1341 Waterbury Democrat, 29 June 1939, p. 4. 